\title{
KRISIS IDENTITAS, PUTUSNYA ESTAFET KEARIFAN LOKAL DAN PENINGKATAN RISIKO BENCANA
}

\author{
Ahmad Cahyadi ${ }^{1}$ \\ 1Jurusan Geografi Lingkungan Fakultas Geografi Universitas Gadjah Mada \\ Email: 1ahmadcahyadi@geo.ugm.ac.id
}

\begin{abstract}
INTISARI
Indonesia telah dikenal sebagai zamrud khatulistiwa dengan sumberdaya alam yang kaya serta lokasi geografis yang dianggap strategis. Artikel ini membahas tentang hilangnya krisis identitas yang ada pada kalangan pemuda yang menyebabkan terputusnya estafet kearifan lokal, terutama terkait dengan bencana. Kearifan lokal dalam manajemen bencana telah terbukti menyelamatkan banyak nyawa dalam berbagai kasus kejadian bencana. Hal ini berarti maka terputusnya estafet kearifan lokal pada generasi mendatang akan menyebabkan terjadinya peningkatan risiko bencana di suatu wilayah.
\end{abstract}

Kata Kunci : Krisis Identitas, Kearifan Lokal, Risiko Bencana

\section{Indonesia Negeri 1001 Bencana}

Sedari kecil, anak-anak Indonesia diajarkan tentang Indonesia yang kaya sumberdaya alam, atau guru saya menyebutkan sebagai "zamrud khatulistiwa". Banyak buku-buku pelajaran yang anak-anak baca, kita akan banyak temukan tentang lokasi Indonesia yang strategis, terletak di antara dua samudra dan dua benua. Namun demikian, mungkin penulis buku-buku itu lupa menuliskan tentang Indonesia yang juga dikenal sebagai negeri 1001 bencana (Sutikno, 2009).

Indonesia terletak pada pertemuan tiga lempeng tektonik yang saling bertumbukan (Verstappen, 2000). Tumbukan antara Lempeng Samudra Hindia-Benua Australia yang bergerak ke Utara dengan Lempeng Benua Eurasia membentuk zona subduksi yang memanjang dari ujung Barat Sumatra sampai dengan Kepulauan Maluku (Sutikno, 2009; Marfai dan Cahyadi, 2012). Disisi lain, tumbukan antara Lempeng Samudra Hindia-Benua Australia membentuk zona subduksi sepanjang Pegunungan Jaya Wijaya di Papua (Sutikno, 2009). Kedua lokasi pertemuan ini berpotensi menimbulkan bencana gempa bumi yang bisa diikuti dengan bencana sekunder seperti longsor dan tsunami (Subandono dan Budiman, 2004). Selain itu, pertemuan lempeng-lempeng tektonik ini membentuk jalur Gunungapi yang aktif. Indonesia setidaknya memilki 129 gunungapi yang tentunya menyebabkan negeri ini rawan terhadap bencana akibat erupsinya.

\section{Kearifan Lokal dan Risiko Bencana}

Secara naluriah, manusia yang hidup di kawasan bencana akan memiliki perilaku adaptasi tertentu (Twigg, 2004, 2007). Perilaku adaptasi ini telah mengalami perubahan dalam waktu yang lama, menyesuaikan terhadap pembelajaran-pembelajaran dari pengalaman yang dilalui oleh beberapa generasi (Adger et.all, 2004). Perilaku adaptasi ini 
diturunkan secara turun temurun dari generasi ke generasi, namun seringkali tidak berupa catatan (Cahyadi dan Setyaningrum, 2013).

Perilaku adaptasi masyarakat terhadap suatu bencana telah terbukti mempertahankan kondisi masyarakat yang ada sekarang (Hardoyo dkk, 2011; Marfai, 2011; Marfai dan Hizbaron, 2011; Fatchurohman, 2013). Perilaku adapatasi terhadap bencana misalnya berupa bentuk rumah yang disesuaikan dengan lingkungannya seperti rumah suku bajau yang bertahan di atas air, rumah suku badui ataupun rumah masyarakat nias yang tahan gempa. Selain itu, perilaku adaptasi masyarakat dapat pula berupa strategi adaptasi masyarakat terhadap kekeringan, strategi menghadapi banjir, penentuan waktu melaut yang tepat atau penentuan pola tanam yang disesuaikan dengan pengalaman dan tanda-tanda alam.

Masyarakat Gunungapi Merapi misalnya, memiliki kearifan lokal yang mampu memahami tanda-tanda akan terjadi erupsi Gunungapi, seperti nampaknya titik api diam di puncak kubah lava. Selain itu masyarakat Gunungapi Merapi memiliki tanda unik untuk menentukan musim hujan segera datang yakni apabila pada daerah Gunungapi Merababu atau Lereng Utara Gunungapi Merapi terjadi kebakaran lahan. Kondisi ini menunjukkan bahwa musim kemarau sudah cukup lama dan suhu semakin meningkat (karena posisi Matahari berada di Selatan khatulistiwa) yang menandakan musim penghujan akan segera datang.

\section{Hilangnya Estafet Kearifan Lokal dan Meningkatnya Risiko Bencana}

Pesatnya perkembangan teknologi informasi menyebabkan pertukaran informasi dari seluruh dunia semakin mudah. Selain informasi yang bermanfaat dalam rangka transfer teknologi dan ilmu pengetahuan, seringkali kondisi ini menyebabkan terjadinya pertukaran ide, gagasan, bahkan adat kebiasaan yang seringkali justru menjadi trend baru di belahan dunia yang lain. Hal ini dapat dilihat dari cara berpakaian, jenis musik, ide dan gagasan tentang pergaulan serta gaya hidup.

Berubahnya budaya, gaya hidup, bahkan identitas sebagai anak bangsa Indonesia kemudian akan menjauhkan pemuda dari nilai-nilai asli yang ada di masyarakat. Pada kondisi inilah kemudian tranfer pengetahuan tentang kearifan lokal, pola adaptasi, dan strategi bertahan hidup yang hidup di masyarakat tidak lagi terjadi. Pada akhirnya estafet kearifan lokal yang kebanyakan tidak tertulis ini akan terputus. Kondisi ini kemudian menciptakan masyarakat yang lebih rentan dan kapasitas masyarakat yang rendah dimasa mendatang, sehingga akan meningkatkan risiko terhadap bencana.

Pemuda-pemuda yang tidak lagi mengenal kearifan lokalnya, tidak akan memiliki kesiap-siagaan yang tinggi terhadap bencana. Hal ini karena mereka tidak tahu lagi tentang tanda-tanda akan terjadinya bencana, strategi bertahan hidup dalam kondisi bencana, serta pola adaptasi yang harus diterapkan untuk dapat bertahan dalam kondisi bencana. Selain itu, masyarakat yang terbentuk dari budaya yang cenderung individualis tidak akan mampu menciptakan suatu modal sosial yang kuat untuk membentuk suatu masyarakat yang tangguh bencana. 
Kisah tentang kearifan lokal "Smong" di Aceh misalnya, merupakan sebuah kearifan lokal berupa seruan untuk segera menuju bukit apabila terjadi gempa bumi. Hal ini karena gempa yang terjadi dapat diikuti dengan tsunami. Kearifan ini lahir dari peristiwa tsunami Tanggal 4 Januari 1907. Lewat cerita dari mulut ke mulut, kearifan ini terus ada hingga terbukti ampuh menyelamatkan banyak nyawa pada kejadian tsunami yang terjadi hampir seratus tahun kemudian ( Tahun 2004). Namun demikian, mungkin kearifan lokal ini tidak sampai di banyak tempat di Aceh dan sekitarnya, sehingga jumlah meninggal mencapai lebih dari 200.000 orang.

Kisah lain tentang ketidak pahaman terhadap kearifan lokal adalah program pemerintah Jawa Tengah yang membangun permukiman nelayan Demak yang awalnya berupa kayu menjadi tembok. Strategi adaptasi berupa menjual sebagian rumah (pintu, jendela, dinding yang terbuat dari kayu) pada saat paceklik ikan atau saat cuaca buruk di laut kemudian tidak dapat dilakukan kembali, sehingga banyak nelayan yang tidak dapat bertahan ketika terjadi paceklik ikan atau cuaca buruk, dan akhirnya terjerat hutang. Kondisi demikian menunjukkan bahwa hilangnya identitas berupa ketidak pahaman terhadap kearifan lokal dari masyarakat kita sendiri dapat menciptakan masyarakat yang sangat rentan dan akhirnya meningkatkan risiko bencana yang lebih besar.

\section{Menyiapkan Generasi Muda Beridentitas}

Generasi muda beridentitas hendaknya disiapkan sedari kecil. Penanaman nilainilai kebangsaan, kearifan lokal dan rasa cinta tanah air hendaknya dilakukan dengan memasukkannya di dalam kurikulum. Masing-masing wilayah memiliki kearifan lokal, maka hendaknya kurikulum juga disiapkan sampai pada tingkat lokal. Tentunya diperlukan kerja ekstra dari guru di tingkat sekolah dasar dan sekolah menenngah untuk menyiapkan hal tersebut.

Selain menyiapkan generasi muda beridentitas melalui kurikulum sekolah, pemerintah hendaknya juga memberikan kesempatan yang luas terhadap pemuda untuk mengakses pendidikan dan pekerjaan. Kondisi ini penting agar generasi muda dapat menggunakan masa mudanya untuk suatu aktifitas yang positif. Dengan demikian mereka tidak akan cukup waktu untuk melakukan hal-hal yang negatif.

Upaya memaksimalkan peran pemuda dalam pembangunan negara dapat dilakukan dengan memfasilitasi organisasi-organisasi kepemudaan yang positif termasuk memfasilitasi organisasi kampus. Hal ini penting sebagai ajang para pemuda untuk mengejawantahkan ide-idenya, sekaligus sebagai sarana untuk pembelajaran menjadi pemimpin masa depan. Dengan adanya pemuda-pemuda yang beridentitas dan berakar budaya bangsa diharapkan estafet kearifan lokal dapat terus berjalan, tentunya dengan berbagai penyempurnaan dengan memanfaatkan teknologi tanpa kehilangan nilai-nilai asalnya. 


\section{DAFTAR PUSTAKA}

Adger, W. N.; Brooks, N.; Bentham, G.; Agnew, M.; dan Eriksen, S. 2004. New Indicators of Vulnerability and Adaptive Capacity. Norwich: Tyndall Centre for Climate Change Research.

Cahyadi, A. dan Setyaningrum, A. 2013. Peranan Modal Sosial (Social Capital) dalam Pemenuhan Kebutuhan Air Domestik di Kawasan Karst Gunungsewu (Studi Kasus Di Dusun Gemulung, Desa Ngeposari, Kecamatan Semanu Kabupaten Gunungkidul, Provinsi Daerah Istimewa Yogyakarta). dalam Sudarmadji; Haryono, E.; Adji, T.N.; Widyastuti, M.; Harini, R.; Nurjani, E.; Cahyadi, A. dan Nugraha, H. (eds) 2013. Ekologi Lingkungan Kawasan Karst Indonesia: Menjaga Asa kelestarian Kawasan Karst Indonesia. Yogyakarta: Deepublish.

Fatchurohman, H.; Cahyadi, A.; Nugroho, H. dan Wacano, D. 2013 Strategi Adaptasi Masyarakat Terhadap Bencana Kekeringan Di Kawasan Karst Kecamatan Panggang, Gunungkidul dalam Sudarmadji; Haryono, E.; Adji, T.N.; Widyastuti, M.; Harini, R.; Nurjani, E.; Cahyadi, A. dan Nugraha, H. (eds) 2013. Ekologi Lingkungan Kawasan Karst Indonesia: Menjaga Asa kelestarian Kawasan Karst Indonesia. Yogyakarta: Deepublish.

Hardoyo, S.R.; Marfai, M.A.; Ni'mah, N.M.; Mukti, R.Y.; Zahro, Q.; Halim, A. 2011. Strategi Adaptasi Masyarakat Terhadap Bencana Banjir Rob di Pekalongan. Yogyakarta: Magister Perencanaan Pengelolaan Pesisir dan Daerah Aliran Sungai dan Cahaya Press.

Marfai, M.A. dan Hizbaron, D.R. 2011. Community's Adaptive Capacity Due to Coastal Flooding in Semarang Coastal City, Indonesia. International Journal of Seria Geografie. Annals of the University of Oradea. E-ISSN 2065-1619. Year XX

Marfai MA. 2011. Jakarta Flood Hazard and Community Participation on Disaster Preparedness. Prosiding dalam seminar Community Preparedness and Disaster Management, Center for Religious and cross-cultural studies, UGMI, no. 2/2011 (December). Hal. 209-221.

Marfai MA, Cahyadi A. 2012. Penentuan Tipologi Pesisir Rawan Tsunami di Provinsi DI. Yogyakarta Berdasarkan Analisis Regional dan Local Site Effect. Jurnal Spasial Vol.10(2). Hal: 1-6.

Subandono, D. dan Budiman. 2008. Hidup Akrab dengan Gempa dan Tsunami. Bogor: Penerbit Buku Ilmiah Populer.

Sutikno. 2009. Indonesia, Negeri 1001 Bencana. Makalah dalam Seminar Sistem Informasi Kebencanaan Sebagai Sebuah Kearifan di Negeri 1001 Bencana 2009. Yogyakarta, 3-5 Desember 2009. Environmental Geography Student Association (EGSA) Fakultas Geografi Universitas Gadjah Mada Yogyakarta.

Twigg, J. 2004. Disaster Risk Reduction, Mitigation and Preparedness in Development and Emergency Programming, Good Practice Review 9. London: Humanitarian Practice Network.

Twigg, J. 2007. Characteristics of a Disaster-Resilient Community : A Guidance Note. DFID Disaster Risk Reduction Interagency Coordination Group.

Verstappen, H.Th. 2000. Outline of The Geomorphology of Indonesia. Enschede: ITC. 
Makalah ini merupakan salah satu chapter dalam buku berjudul "Pengelolaan Lingkungan Zamrud Khatulistiwa”, dengan Editor Muh Aris Marfai dan M. Widyastuti. Buku ini diterbitkan di Yogyakarta Tahun 2013 oleh Penerbit Pintal. Makalah ini dimuat di halaman 114-118. 